\title{
The Two-Front Forever War: Moral Nativism and Its Critics
}

\author{
Commentary on Carpendale, Müller, Wallbridge, Broesch, Cameron-Faulkner, and Ten Eycke
}

\author{
Audun Dahl Charles P. Baxley Talia Waltzer
}

University of California, Santa Cruz, CA, USA

\section{Keywords}

Morality · Nativism · Development · Biology · Infancy

Two or three decades ago, the so-called heredity-environment question was the center of lively controversy. Today, on the other hand, many psychologists look upon it as a dead issue. It is now generally conceded that both hereditary and environmental factors enter into all behavior. (Anastasi, 1958, p. 197)

For over a century, developmental psychologists have debated whether morality is innate (Allen \& Bickhard, 2013; Antipoff, 1928; Bloom, 2013; Piaget, 1932; Tremblay et al., 1999; Turiel, 2015a). Before the era of developmental psychology, philosophers debated for centuries whether humans are, by nature, good or evil (Hobbes, 1651; Plato, 1998; Rousseau, 1762). The developmental debate about moral nativism resurfaced in the late 2000s, after the publication of studies that, to many scholars, demonstrated morally relevant abilities in infants (Hamlin et al., 2007; Warneken \& Tomasello, 2006; for discussion, see Dahl, 2019; Hamlin, 2013; Thompson, 2012; Smetana, 2018). These claims in turn informed cognitive, evolutionary, and social psychological accounts of morality (Graham et al., 2013; Haidt, 2012; Haidt \& Joseph,
2008; Hauser, 2007). While the terms of the debate have shifted - "innate," "core," "first draft," and "natural," to mention a few examples - the basic question of moral nativism remains: Do some parts of human morality emerge independently of learning and experience?

After a century of data collection, we might expect that moral developmentalists would have settled this question and moved on. Yet, moral developmentalists have not settled this question, and Carpendale et al. (this issue, DOI $10.1159 / 000517221$ ) remind us why. Alongside the empirical debate - about whether morality is innate - runs a second, paradigmatic debate that interferes with the empirical one (Witherington, 2015). That paradigmatic debate is about whether it even makes sense to separate morality into those components that are innate and those that are not. Carpendale et al. (this issue), among others, reject the dichotomy between innate and noninnate characteristics, and they propose instead that biological contributions are inseparable from environmental contributions to development (see also Allen \& Bickhard, 2013; Gottlieb, 2007; Lickliter \& Honeycutt, 2010; Piaget, 1932; Spencer et al., 2009). We may therefore call the moral nativism debate a two-front war: moral nativists argue both against scholars who propose that morality is learned rather than
C 2021 The Author(s)

Published by S. Karger AG, Basel

This is an Open Access article licensed under the Creative Common Attribution-NonCommercial-4.0 International License (CC BY-NC) (http://www.karger.com/Services/OpenAccessLicense), applicable to the online version of the article only. Usage and distribution for commercial purposes requires written permission.
Correspondence to:

AudunDahl,dahl@ucsc.edu 
Table 1. Overview of some common assumptions underlying the two debates about moral nativism

\begin{tabular}{lll}
\hline Debate & Central question & Common assumptions \\
\hline Empirical debate & $\begin{array}{l}\text { Are moral capabilities innate } \\
\text { or learned? }\end{array}$ & $\begin{array}{l}\text { All moral capabilities are either innate or learned } \\
\text { Innate capabilities are those that emerge prior to relevant experiences and } \\
\text { that confer evolutionary benefits }\end{array}$ \\
\hline Paradigmatic debate & $\begin{array}{l}\text { Can we separate innate and } \\
\text { learned moral capabilities? }\end{array}$ & $\begin{array}{l}\text { The separation of innate and learned characteristics fails to incorporate } \\
\text { biological evidence } \\
\text { The separation of innate and learned characteristics fails to account for the } \\
\text { developing, reciprocal connections between cognition and action }\end{array}$ \\
\hline
\end{tabular}

innate and against scholars who reject the innate-learned dichotomy altogether. The two-front conflict over moral nativism - going on a hundred years - has the makings of a forever war.

In philosophy, more explicitly than in psychology, many scholars have pondered why some age-old problems resist resolution. Carpendale et al. (this issue) invoke one such philosopher: Ludwig Wittgenstein. With renowned ingenuity, Wittgenstein (1953) sought to dissolve longstanding philosophical problems by showing how these problems stemmed from misunderstandings or misuses of language (Biletzki \& Matar, 2020; Crary \& Read, 2002). Once philosophers saw these misunderstandings, Wittgenstein thought, they would be freed from the problem. He wrote that his goal in philosophy was to show "the fly the way out of the fly-bottle" (Wittgenstein, 1953, p. 103). For instance, Wittgenstein suggested that when philosophers ask about the meaning of some term, like "game" or "morality," they often assume that all usages of the term share the same meaning. These philosophers wrongly suppose, said Wittgenstein, that we could not use the word "game" unless all games had some shared essence. Against this supposition, Wittgenstein (1953) proposed that the things we call "game" or "morality" share "family resemblances," but no one unifying character (p. 32). Game A might resemble game $\mathrm{B}$ in one way and game $\mathrm{C}$ in another: there may be no one essence that unites board games, game animals, and Olympic games. Wittgenstein examined not only how we answer our questions but also how we pose them - and, especially, which assumptions we make in posing those questions.

In the rest of this commentary, we will examine assumptions that underlie the two debates about moral nativism (Table 1). First, we will consider the empirical debate about whether moral capabilities are innate or learned. Second, we will consider the paradigmatic debate about whether we can even separate what is innate from

The Two-Front Forever War: Moral Nativism and Its Critics what is learned. Taking inspiration from Wittgenstein, we will propose two possible truces for the debates about moral nativism. Regardless of what happens to moral nativism, we will conclude that the approach of Carpendale et al. (this issue) to the development of giving exemplifies a fruitful path forward in research on early moral development.

\section{The Empirical Debate: Are Moral Capabilities Innate or Learned?}

Very often, the distinction between innate and learned characteristics is assumed rather than justified. Many discussions of nativism start with the premise that some characteristics are innate whereas other characteristics are learned, treating the two terms as exhaustive and mutually exclusive. Spelke and Kinzler (2009) write that "innate means not learned, and so claims of innateness and learning are mutually dependent" (p. 96, see also Bloom, 2012). A further clarification is that innate does not generally mean "present at birth," since very little research taken to support moral nativism collects data from newborns. Rather, innate is taken to mean something that emerges prior to, or independently of, relevant experiences, even if it is not evident until well after birth. With this starting point, researchers deploy empirical methods to determine which characteristics are innate and which are learned.

In research on early morality, claims that some characteristic is innate usually draws on three sources of evidence. The first, and perhaps most important, is early emergence. Nearly all claims about innate moral capabilities involve research with infants, be it about moral judgments, principles of justice, or altruistic motives (Bian et al., 2018; Bloom, 2013; Hamlin, 2013; Warneken, 2016). This research has documented morally relevant 
looking preferences, reaching preferences, or helping actions in infants in the first year or so after birth (Hamlin et al., 2007, 2010; Margoni \& Surian, 2018; Sommerville et al., 2013; Warneken \& Tomasello, 2007). Early by itself is not enough, however, since we have no cutoff for deciding what age is "early enough" to constitute evidence for innateness: at times, scholars have argued that even 2 or 3 years of age was too early for children to have learned moral capabilities through experience (Antipoff, 1928; Dwyer, 2007). This brings us to the next kind of evidence used to infer innate capabilities.

The second kind of evidence is the lack of relevant experience - the so-called "poverty of the stimulus" argument (Chomsky, 1980; Dwyer, 2007; Hamlin \& Wynn, 2011; Warneken \& Tomasello, 2009). This piece of evidence is rarely subjected to empirical tests, yet it is nevertheless crucial for the debate over whether some moral characteristic is innate (Dahl, 2017). Authors proposing a nativist account of some moral characteristic often suggest that infants lack the necessary experiences to learn that moral characteristic - hence, the characteristic must be innate. For instance, Hamlin and Wynn (2011) wrote that it is "unlikely that infants have been sufficiently socialized, by three, five, or even nine months of age, to distinguish between the positive and negative intentions of social others to an extent that would explain" infants' preferences for helpful characters (p. 245). Such preferences have been taken to reflect an innate moral sense that develops in the absence of relevant social experiences (Bloom, 2013; Haidt, 2012; Hamlin, 2013).

The third piece of evidence is the evolutionary value of the behavior. To explain why some moral capability would emerge independently of experiences, nativist accounts typically assert that the capability evolved because it conferred some evolutionary benefit. Some have argued, for instance, that the ability to detect cheaters or other individuals who violate moral principles allowed human groups to cooperate more effectively (see e.g., Bian et al., 2018; Fehr \& Fischbacher, 2004; Hamlin, 2014). Since the ability to detect cheaters made humans more likely to survive and pass on their genes, genes that encoded such cheater detection could be selected for across evolutionary time. Of course, evolutionary benefit could at most be a necessary criterion for nativism, and never a sufficient one. Even characteristics that are highly valuable for survival, such as wariness of heights, may depend on specific experiences, such as self-produced locomotion (Dahl et al., 2013).

Of the three types of evidence, the first - early emergence - has received the most empirical scrutiny. Since the mid-2000s, an abundance of studies has examined infants' looking and reaching toward helpful characters, their reactions to inequitable distributions, and their propensities to help others (see Hamlin, 2013; Margoni \& Surian, 2018; Paulus, 2014; Warneken, 2016). Moral nativists have taken these findings as evidence for innate moral capabilities.

The second - the poverty of the social stimulus - has received far less attention. This is unfortunate, because evidence about the lack of relevant experience is indispensable for the nativist account of morality. What counts as emerging prior to relevant experiences depends on what kinds of experiences infants have in their everyday lives (Dahl, 2017). When researchers have examined the everyday experiences of infants, the "stimulus" has turned out to be far richer than often assumed. Whereas researchers at one time speculated that infants rarely received encouragement to help at home, naturalistic studies and parental reports showed that parents routinely encouraged and praised infant helping in everyday life (Carpendale et al., 2015; Dahl, 2015). The third type of evidence - evolutionary benefit - has received indirect support from theoretical arguments and statistical modelling but is difficult to test directly, since we have limited access to evolutionary processes that took place over hundreds of thousands, or even millions, of years (Nowak \& Sigmund, 2005). The most critical issue thus remains the second one: Just how impoverished is the moral stimulus?

Recognizing the wealth of the moral stimulus, some authors have abandoned moral nativism in favor of other nativisms. Tasimi (2020), for instance, rejects moral nativism in favor of the view that "what is innate is the machinery that enables infants to build social knowledge such that different infants can construct different knowledge representations" (p. 399, see also Köster \& Kärtner, 2019; Sommerville, 2018). This response - that if morality is not innate something else must be innate - is indeed the only option, if we begin with the premise that all characteristics are either innate or learned. This premise, as we will see in the next section, is not universally accepted.

If this first, empirical debate was the only debate that scholars could continue to collect more and more data on what infants can do, and what they experience, earlier and earlier in life. This research would also need to include similar evidence of early emergence and social experiences in non-Western communities, in addition to the Western communities from which most of the current evidence comes (Amir \& McAuliffe, 2020). This body of research would, presumably, converge on the asymptote of whatever it is that most infants can do given the kinds of 
experiences most infants receive. If this asymptote turned out to contain moral traits, and those traits seemed beneficial for passing on our genes, the field would eventually conclude that some moral capabilities are innate. The trouble is that this first debate is not the only debate. It is the existence of a second front that threatens to turn the battle over moral nativism into a forever war.

\section{The Paradigmatic Debate: Can We Separate Innate and Learned Moral Capabilities?}

Many scholars do not accept the dichotomy between innate and learned characteristics (Allen \& Bickhard, 2013; Carpendale et al., this issue; Lickliter \& Honeycutt, 2010; Spencer et al., 2009; Witherington, 2015). Rather, they have recommended that developmental psychologists, in Allen and Bickhard's (2013) words, "step off the pendulum" and end the battle between nativism and empiricism. Instead of separating morality into innate and learned parts, these authors propose we should seek to study developmental processes that involve the coaction of environmental, genetic, and other components. (We, too, have written in this tradition: Dahl, 2019; Dahl et al., 2018; Dahl \& Baxley, in press.) Once we do so, these scholars propose new and more fruitful avenues of inquiry will open.

Developmental scientists have rejected the innatelearned dichotomy on at least two grounds. Carpendale et al. (this issue) exemplify them both. Biological implausibility is the first ground for rejecting the dichotomy. Like many other scholars, Carpendale and colleagues argue that biological research contradicts the claims of moral nativism. They note that all developments involve coactions among genetic, neurological, behavioral, and environmental components (Gottlieb, 1991, 2007; Lickliter \& Honeycutt, 2010; Moore, 2015; Spencer et al., 2009). Genes do not provide blueprints for moral or other characteristics, nor do they single-handedly cause the emergence of such characteristics. Left to themselves, genes do nothing (Moore, 2015). In the words of Lickliter and Honeycutt (2010), "genetic and nongenetic factors cannot be meaningfully partitioned when accounting for developmental outcomes" (p. 37). If no psychological characteristics can be attributed to genes, these authors argue, the contrast between innate and learned characteristics becomes meaningless.

Of course, genetic variability can predict phenotypic variability. Some genotypes foretell blue eyes, and others foretell brown eyes. In the moral realm, researchers have

The Two-Front Forever War: Moral Nativism and Its Critics found evidence for genetic correlates of empathy (Knafo et al., 2008; Zahn-Waxler et al., 1992). However, statistically significant predictive relations between genotypes and phenotypes say little about the causal processes that create phenotypic variability. Most importantly for the present purposes, no numeric measure of heritability could demonstrate that genes are somehow more important than environments (Lewontin, 1974; Turkheimer, 2000). For many scholars, the question of whether genes or environments are more important for the development of some characteristic has no clear biological meaning.

A second argument against the innate-learned dichotomy is that it misconstrues the relation between cognition and action (see Carpendale et al., this issue; Allen \& Bickhard, 2013; Kagan, 2008). Although this critique has taken many forms, a basic idea is that moral nativism fails to account for how innate representations, such as principles of justice, first arise and then guide actions, such as looking behaviors. Interactions with the environment, some scholars have argued, are necessary to explain both how infants create representations and how those representations are applied, for instance to determine which actions are fair and which are unfair. As these arguments are quite complex, we will not elaborate on them here, but instead refer the readers to elaborations elsewhere (Allen \& Bickhard, 2013; Carpendale et al., this issue). Without judging the merits of this critique here, we merely note that it constitutes one more challenge to the innatelearned dichotomy that underlies many debates about moral nativism.

Nativist responses to these critiques have taken several forms. Some authors have defended the innatelearned dichotomy by arguing that development has to start somewhere (Landau, 2009; Marcus, 2001). Nativism, it is said, is a theory about what that starting point is; moral nativism is a theory about the starting point of moral development. Other authors have argued that debates about nativism have generated valuable scholarship and research. Spelke and Kinzler (2009), for instance, argued that the nativist-empiricist debate has both promoted "understanding of currently known phenomena" and "fostered new lines of research" for several millennia (pp. 96-97). Hence, Spelke and Kinzler argued the nativism debates have accomplished, and will continue to accomplish, what good scientific debates are supposed to.

Nativist rebuttals have not ended the paradigmatic debate about moral nativism. On the contrary, the nativist rebuttals illustrate why the paradigmatic debate is so difficult to resolve. What nativists may see as logical neces- 
sities (development must start somewhere), nonnativists see as logical impossibilities (development involves constant coaction among biological and environmental components). What nativists see as a fruitful debate (what is innate and what is learned?), nonnativists see as wrongheaded (we cannot separate morality into innate and learned parts). The paradigmatic debate thus appears locked in disagreements over scientific logic and scientific value, neither of which can be resolved by empirical data alone.

\section{A Wittgensteinian Truce: Future Paths for Moral Nativism}

The two parallel debates about moral nativism undermine each other to create what we called a two-front forever war. The paradigmatic debate about whether to reject the innate-learned distinction threatens to render the methodological debate pointless. The methodological debate, and its production of empirical data, appears to render the paradigmatic moot by showing how the innatelearned dichotomy produces interesting empirical data. Hence, it is no wonder that debates about moral nativism remain unresolved and - even more troubling - without any promise of resolution.

When, in a century-old scientific debate, we cannot imagine which data would ever resolve the disagreements, we have reason to step back. Wittgenstein (1953) suggested that, when faced with unresolvable questions, we should retrace our steps and reflect on the assumptions that brought us here: "The first step is the one that altogether escapes notice. [...] But that is just what commits us to a particular way of looking at the matter" (p. 103). In this commentary, we retraced steps that underlie the empirical and paradigmatic debates about moral nativism. We noted, for instance, how the empirical debate has assumed that all moral characteristics are either innate or learned, and how the paradigmatic debate has assumed that the innate-learned dichotomy must be rooted in biological evidence.

Our discussion points to two possible paths forward, each representing a truce. Inspired by Wittgenstein, each truce calls on scholars to clarify, and possibly redefine, assumptions that sustain debates about moral nativism. The first possible path is that of clean separation. That is, those who participate in the empirical debate about nativism could make clear that they are not offering a biological account of innate characteristics. Rather, they seek to identify the earliest, culturally invariant occurrence of morally relevant characteristics. This would require a clarification - or even redefinition - of what nativism means. It is possible that this redefinition would deprive nativism of some of its theoretical appeal. Still, it is one way of separating the empirical debate about nativism from the paradigmatic debate about whether we can meaningfully distinguish innate from learned characteristics. Meanwhile, those who seek to study the development of infant morality, not just to identify its earliest and most culturally invariant instances, would still need to incorporate findings about infants' early characteristics into their theories of moral development. For instance, theories about the emergence of instrumental helping need to incorporate evidence on infants' preferences for helpful characters early in the first year (Dahl, 2019; Köster et al., 2016).

The second path is that of a merger. On this path, nativist theories would need to offer a biological and developmental account of how innate characteristics emerge, change, and shape infants' actions. For instance, what does it mean - at the level of biological processes - to provide a "first draft of the moral mind" (Graham et al., 2013, p. 63)? How, biologically, do our bodies translate this draft into a full-fledged morality? This path, too, would require a clarification or redefinition of what "innate" means, now in explicitly biological terms. Participants in the paradigmatic debate may still disagree about how to best formulate a notion of innateness that is biologically plausible and testable, but they could no longer reject the notion of innate characteristics outright.

An entirely different option, which is neither a truce nor a likely outcome, is that moral developmentalists will stop talking about innate moral characteristics altogether. Although this is what many nonnativists propose in the paradigmatic debate, we do not think it is a likely outcome. After more than a century of seeking to end the debates over moral nativism, the past 20 years have shown that these debates are as lively as ever.

\section{Coda}

Regardless of which path the field takes, research on early moral development will benefit from the approach sketched by Carpendale et al. (this issue). Nativists and nonnativists agree that a long developmental sequence separates infants' social preferences from adults' moral concerns with welfare, rights, justice, and fairness (Dahl \& Killen, 2018). To account for this developmental sequence, from the food sharing of infants to the heroic al- 
truism of adults, moral developmentalists need to account for changes in the moral meaning of similar behaviors from infancy to adulthood (Bar-Tal, 1982; Dahl \& Paulus, 2019; Hay \& Cook, 2007). Moral developmentalists need to consider, for instance, how an infant might hand a pen to an adult to engage in a social interaction, whereas an adult might hand a pen to make a crime suspect sign a forced confession - or to celebrate the signing of a Civil Rights bill (Dahl et al., 2020; Turiel, 2015b). Like Carpendale et al. (this issue), we believe that the path to better explanations of transformations in moral development will involve careful attention to children's everyday interactions. We add, however, that this path will also require the rigorous experimental methods that moral developmentalists - including moral nativists - have honed over the past century (Dahl, 2017).

Whatever happens to moral nativism in the next century, we hope that future research on early moral development will build on lessons of its past. The lessons concern the empirical advances about the capabilities and experiences of young infants, the benefits of combining naturalistic and experimental methods to study developmental processes, and the imperative to either redefine what we mean by "innate" or avoid the term altogether.

\section{Acknowledgements}

We thank members of the Developmental Moral Psychology Lab at the University of California, Santa Cruz, for helpful comments on earlier versions of this paper.

\section{Statement of Ethics}

No ethical approval was required for the preparation of this manuscript, as no human or animal subjects were used.

\section{Conflict of Interest Statement}

The authors have no conflicts of interest to declare.

\section{Funding Sources}

The writing of this paper was supported, in part, by a grant from the National Institute of Child Health and Human Development (R03HD087590).

\section{Author Contributions}

A. Dahl, T. Waltzer, and C.P. Baxley wrote and edited the paper.

\section{References}

Allen, J. W. P., \& Bickhard, M. H. (2013). Stepping off the pendulum: Why only an actionbased approach can transcend the nativistempiricist debate. Cognitive Development, 28(2), 96-133. https://doi.org/10.1016/j.cogdev.2013.01.002

Amir, D., \& McAuliffe, K. (2020). Cross-cultural, developmental psychology: Integrating approaches and key insights. Evolution and $\mathrm{Hu}$ man Behavior, 41(5), 430-444. https://doi. org/10.1016/j.evolhumbehav.2020.06.006

Anastasi, A. (1958). Heredity, environment, and the question how? Psychological Review, 65(4), 197-208. https://doi.org/10.1037/h0044895

Antipoff, H. (1928). Observations sur la compassion et le sense de la justice chez l'enfant. Archives de Psychologie, 21, 208-214.

Bar-Tal, D. (1982). Sequential development of helping behavior: A cognitive-learning approach. Developmental Review, 2(2), 101-124. https:// doi.org/10.1016/0273-2297(82)90006-5

Bian, L., Sloane, S., \& Baillargeon, R. (2018). Infants expect ingroup support to override fairness when resources are limited. Proceedings of the National Academy of Sciences of the United States of America, 115(11), 2705-2710. https:// doi.org/10.1073/pnas.1719445115
Biletzki, A., \& Matar, A. (2020). Ludwig Wittgenstein. In E. N. Zalta (Ed.), The Stanford encyclopedia of philosophy (spring 2020). Metaphysics Research Lab, Stanford University. https://plato.stanford.edu/archives/spr2020/ entries/wittgenstein/

Bloom, P. (2012). Moral nativism and moral psychology. In M. Mikulincer \& P. R. Shaver (Eds.), The social psychology of morality: Exploring the causes of good and evil (pp. 71-89). American Psychological Association. https:// doi.org/10.1037/13091-004

Bloom, P. (2013). Just babies: The origins of good and evil. Crown.

Carpendale, J. I. M., Kettner, V. A., \& Audet, K. N. (2015). On the nature of toddlers' helping: Helping or interest in others' activity? Social Development, 24(2), 357-366. https://doi. org/10.1111/sode. 12094

Carpendale, J. I. M., Müller, U., Wallbridge, B., Broesch, T., Cameron-Faulkner, T., \& Ten Eycke, K. (2021). The development of giving in forms of object-exchange: Exploring the roots of communication and morality in early interaction around objects. Human Development, 65, this issue. https://doi.org/ $10.1159 / 000517221$
Chomsky, N. (1980). Rules and representations. Columbia University Press. https://doi. org/10.1017/S0140525X00001515

Crary, A., \& Read, R. (Eds.). (2002). The new Wittgenstein. Routledge. https://doi.org/10.4324/ 9780203449400

Dahl, A. (2015). The developing social context of infant helping in two US samples. Child Development, 86(4), 1080-1093. https://doi. org/10.1111/cdev.12361

Dahl, A. (2017). Ecological commitments: Why developmental science needs naturalistic methods. Child Development Perspectives, 11(2), 79-84. https://doi.org/10.1111/cdep. 12217

Dahl, A. (2019). The science of early moral development: On defining, constructing, and studying morality from birth. Advances in Child Development and Behavior, 56, 1-35. https://doi.org/10.1016/bs.acdb.2018.11.001

Dahl, A., \& Baxley, C. (in press). Early moral development. In J. Benson \& C. A. Brownell (Eds.), Encyclopedia of infant and early childhood development (version 2, 2nd ed.). Academic Press. https://doi.org/10.1016/B978-012-809324-5.06490-7 
Dahl, A., Campos, J. J., Anderson, D. I., Uchiyama, I., Witherington, D. C., Ueno, M., ... Barbu-Roth, M. (2013). The epigenesis of wariness of heights. Psychological Science, 24(7), 1361-1367. https://doi.org/10.1177/ 0956797613476047

Dahl, A., Gross, R. L., \& Siefert, C. (2020). Young children's judgments and reasoning about prosocial acts: Permission, obligation, and supererogation. Cognitive Development, 55, 100908. https://doi.org/10.1016/j.cogdev. 2020.100908

Dahl, A., \& Killen, M. (2018). A developmental perspective on the origins of morality in infancy and early childhood. Frontiers in Psychology, 9, 1736. https://doi.org/10.3389/ fpsyg.2018.01736

Dahl, A., \& Paulus, M. (2019). From interest to obligation: The gradual development of human altruism. Child Development Perspectives, 13(1), 10-14. https://doi.org/10.1111/ cdep. 12298

Dahl, A., Waltzer, T., \& Gross, R. L. (2018). Helping, hitting, and developing: Toward a constructivist-interactionist account of early morality. In C. C. Helwig (Ed.), New perspectives on moral development. Psychology Press.

Dwyer, S. (2007). How good is the linguistic analogy? In Peter Carruthers, S. Laurence, \& S. P. Stich (Eds.), The innate mind: Vol. 2. Culture and cognition (pp. 145-167). Oxford University Press.

Fehr, E., \& Fischbacher, U. (2004). Third-party punishment and social norms. Evolution and Human Behavior, 25(2), 63-87. https://doi. org/10.1016/S1090-5138(04)00005-4

Gottlieb, G. (1991). Experiential canalization of behavioral development: Theory. Developmental Psychology, 27(1), 4-13. https://doi. org/10.1037/0012-1649.27.1.4

Gottlieb, G. (2007). Probabilistic epigenesis. Developmental Science, 10(1), 1-11. https://doi. org/10.1111/j.1467-7687.2007.00556.x

Graham, J., Haidt, J., Koleva, S., Motyl, M., Iyer, R., Wojcik, S. P., \& Ditto, P. H. (2013). Moral foundations theory: The pragmatic validity of moral pluralism. Advances in Experimental Social Psychology, 47, 55-130. https://doi. org/10.1016/B978-0-12-407236-7.00002-4

Haidt, J. (2012). The righteous mind: Why good people are divided by politics and religion. Vintage.

Haidt, J., \& Joseph, C. (2008). The moral mind: How five sets of innate intuitions guide the development of many culture-specific virtues, and perhaps even modules. In P. Carruthers, S. Laurence, \& S. Stich (Eds.), The innate mind: Vol. 3. Foundations and the future (pp. 367-391). Oxford University Press.

Hamlin, J. K. (2013). Moral judgment and action in preverbal infants and toddlers: Evidence for an innate moral core. Current Directions in Psychological Science, 22(3), 186-193. https://doi.org/10.1177/0963721412470687
Hamlin, J. K. (2014). The origins of human morality: Complex socio-moral evaluations by preverbal infants. In J. Decety \& Y. Christen (Eds.), New frontiers in social neuroscience (Vol.21, pp. 165-188). Springer International Publishing. https://doi.org/10.1007/978-3319-02904-7_10

Hamlin, J. K., \& Wynn, K. (2011). Young infants prefer prosocial to antisocial others. Cognitive Development, 26(1), 30-39. https://doi. org/10.1016/j.cogdev.2010.09.001

Hamlin, J. K., Wynn, K., \& Bloom, P. (2007). Social evaluation by preverbal infants. Nature, 450(7169), 557-559. https://doi.org/10.1038/ nature 06288

Hamlin, J. K., Wynn, K., \& Bloom, P. (2010). Three-month-olds show a negativity bias in their social evaluations. Developmental Science, 13(6), 923-929. https://doi.org/10.1111/ j.1467-7687.2010.00951.x

Hauser, M. (2007). Moral minds: The nature of right and wrong. Harper Collins.

Hay, D. F., \& Cook, K. V. (2007). The transformation of prosocial behavior from infancy to childhood. In C. A. Brownell \& C. B. Kopp (Eds.), Socioemotional development in the toddler years (pp. 100-131). Guilford Press.

Hobbes, T. (1651). Leviathan. Cambridge University Press.

Kagan, J. (2008). In defense of qualitative changes in development. Child Development, 79(6), 1606-1624. https://doi. org/10.1111/j.1467-8624.2008.01211.x

Knafo, A., Zahn-Waxler, C., Van Hulle, C., Robinson, J. L., \& Rhee, S. H. (2008). The developmental origins of a disposition toward empathy: Genetic and environmental contributions. Emotion (Washington, DC), 8(6), 737-752. https://doi.org/10.1037/a0014179

Köster, M., \& Kärtner, J. (2019). Why do infants help? A simple action reveals a complex phenomenon. Developmental Review, 51, 175187. https://doi.org/10.1016/j.dr.2018.11.004

Köster, M., Ohmer, X., Nguyen, T. D., \& Kärtner, J. (2016). Infants understand others' needs. Psychological Science, 27(4), 542-548. https:// doi.org/10.1177/0956797615627426

Landau, B. (2009). The importance of the nativistempiricist debate: Thinking about primitives without primitive thinking. Child Development Perspectives, 3(2), 88-90. https://doi. org/10.1111/j.1750-8606.2009.00082.x

Lewontin, R. C. (1974). Annotation: The analysis of variance and the analysis of causes. American Journal of Human Genetics, 26(3), 400411.

Lickliter, R., \& Honeycutt, H. (2010). Rethinking epigenesis and evolution in light of developmental science. In M. S. Blumberg, J. Freeman, \& S. R. Robinson (Eds.), Oxford handbook of developmental behavioral neuroscience (pp. 30-47). Oxford University Press.
Marcus, G. F. (2001). Plasticity and nativism: Towards a resolution of an apparent paradox. In S. Wermter, J. Austin, \& D. Willshaw (Eds.), Emergent neural computational architectures based on neuroscience (pp. 368382). Springer. https://doi.org/10.1007/3540-44597-8_27

Margoni, F., \& Surian, L. (2018). Infants' evaluation of prosocial and antisocial agents: A meta-analysis. Developmental Psychology, 54(8), 14451455. https://doi.org/10.1037/dev0000538

Moore, D. S. (2015). The developing genome: An introduction to behavioral epigenetics. Oxford University Press.

Nowak, M. A., \& Sigmund, K. (2005). Evolution of indirect reciprocity. Nature, 437(7063), 12911298. https://doi.org/10.1038/nature04131

Paulus, M. (2014). The emergence of prosocial behavior: Why do infants and toddlers help comfort, and share? Child Development Perspectives, 8(2),77-81.https://doi.org/10.1111/ cdep.12066

Piaget, J. (1932). The moral judgment of the child. Free Press.

Plato (1998). Plato's Ion \& Meno. Agora Publications.

Rousseau, J.-J. (1762). The social contract. Penguin.

Smetana, J. G. (2018). Becoming moral: Introduction to the special issue on early moral development. Human Development, 61(4-5), 209213. https://doi.org/10.1159/000492799

Sommerville, J. A. (2018). Infants' understanding of distributive fairness as a test case for identifying the extents and limits of infants' sociomoral cognition and behavior. Child Development Perspectives, 12(3), 141-145. https://doi. org/10.1111/cdep.12283

Sommerville, J. A., Schmidt, M. F. H., Yun, J., \& Burns, M. (2013). The development of fairness expectations and prosocial behavior in the second year of life. Infancy, 18(1), 40-66. https://doi.org/10.1111/j.1532-7078. 2012.00129.x

Spelke, E. S., \& Kinzler, K. D. (2009). Innateness, learning, and rationality. Child Development Perspectives, 3(2), 96-98. https://doi. org/10.1111/j.1750-8606.2009.00085.x

Spencer, J. P., Blumberg, M. S., McMurray, B., Robinson, S. R., Samuelson, L. K., \& Tomblin, J. B. (2009). Short arms and talking eggs: Why we should no longer abide the nativist-empiricist debate. Child Development Perspectives, 3(2), 79-87. https://doi.org/10.1111/ j.1750-8606.2009.00081.x

Tasimi, A. (2020). Connecting the dots on the origins of social knowledge. Perspectives on Psychological Science, 15(2), 397-410. https://doi. org/10.1177/1745691619885861

Thompson, R. A. (2012). Whither the preconventional child? Toward a life-span moral development theory. Child Development Perspectives, 6(4), 423-429. https://doi.org/10.1111/ j.1750-8606.2012.00245.x 
Tremblay, R. E., Japel, C., Perusse, D., McDuff, P., Boivin, M., Zoccolillo, M., \& Montplaisir, J. (1999). The search for the age of "onset" of physical aggression: Rousseau and Bandura revisited. Criminal Behaviour and Mental Health, 9(1), 8-23. https://doi.org/10.1002/ cbm. 288

Turiel, E. (2015a). Moral development. In R. M. Lerner (Ed.), Handbook of child psychology and developmental science (Vol. 1, pp. 484522). John Wiley \& Sons. https://doi. org/10.1002/9781118963418.childpsy113

Turiel, E. (2015b). Morality and prosocial judgments and behavior. In D. A. Schroeder \& W. G. Graziano (Eds.), The Oxford handbook of prosocial behavior (pp. 137-152). Oxford University Press.
Turkheimer, E. (2000). Three laws of behavior genetics and what they mean. Current Directions in Psychological Science, 9(5), 160-164. https://doi.org/10.1111/1467-8721.00084

Warneken, F. (2016). Insights into the biological foundation of human altruistic sentiments. Current Opinion in Psychology, 7, 51-56. https://doi.org/10.1016/j.copsyc.2015.07.013

Warneken, F., \& Tomasello, M. (2006). Altruistic helping in human infants and young chimpanzees. Science, 311(5765), 1301-1303. https://doi.org/10.1126/science.1121448

Warneken, F., \& Tomasello, M. (2007). Helping and cooperation at 14 months of age. Infancy, 11(3), 271-294. https://doi.org/10.1111/ j.1532-7078.2007.tb00227.x
Warneken, F., \& Tomasello, M. (2009). The roots of human altruism. British Journal of Psychology, 100(Pt 3), 455-471. https://doi.org/ $10.1348 / 000712608 X 379061$

Witherington, D. C. (2015). On the need to seriously challenge the empiricist side of the nativist-empiricist debate. Research in Human Development, 12(3-4), 172-177. https://doi. org/10.1080/15427609.2015.1068056

Wittgenstein, L. (1953). Philosophical investigations (G. E. Anscombe, Trans.). Basil Blackwell.

Zahn-Waxler, C., Robinson, J. L., \& Emde, R. N. (1992). The development of empathy in twins. Developmental Psychology, 28(6), 1038-1047. https://doi.org/10.1037/00121649.28.6.1038 